\title{
INTERACTIVE VIDEO AS ENGLISH TEACHING MATERIALS FOR SPEAKING
}

\section{Gde Putu Agus Pramerta}

English Language Education Study Program, Faculty of Teacher Training and Education

Mahasaraswati Denpasar University

Email: putuagus1708@gmail.com

\begin{abstract}
ABSTRAK
Proses pembelajaran bahasa Inggris di SMP N 2 Penebel kelas VII C menunjukkan bahwa siswa mengalami kendala dalam kemampuan berbicara. Hal tersebut terlihat dari nilai pre-test siswa untuk kemampuan berbicara adalah 2,70 masih di bawah KKM yaitu 3,0. Peneliti mengindikasikan bahwa rendahnya kemampuan berbicara akibat dari kurangnya motivasi siswa dalam proses pembelajaran bahasa Inggris. Penggunaan media video interaktif dalam pembelajaran dipandang perlu dalam rangka peningkatan motivasi siswa dalam berbicara. Setelah melakukan pre-test, peneliti masuk ke siklus 1 yang yang berhasil meningkatkan kemampuan berbicara dari 2,70 menjadi 2,96. Pada siklus 2 kembali terjadi peningkatan 2,96 menjadi 3,31. Selain peningkatan kemampuan berbicara, media video interaktif mampu meningkatkan motivasi siswa dalam pembelajaran.
\end{abstract}

Kata kunci: pembelajaran, videointeraktif, kemampuan berbicara, motivasi

\begin{abstract}
The process of learning English in SMP N 2 Penebel class VII C showed that students experienced obstacles in speaking. It could be seen from result of observation, interview and pre-test. It was 2.70 which is categorized below the passing grade minimum criteria: 3.0. Researcher indicated that it was because they seemed to be having lack of motivation in the English learning process. The use of interactive video in learning is necessary in order to improve students' motivation in speaking. Action research design was accommodated to help their problems. The researcher offered three kinds of tests. The result of pre-test was 2.70 . After pre-test, the researcher went into cycle 1 which succeeded in improving their speaking from 2.70 to 2.96 . In cycle 2, there was improvement up to 3.31. The use of interactive video gave positive responses to the students. As the result, their speaking could be improved.
\end{abstract}

Keywords: learning, interactive video, speaking skills, motivation

\section{INTRODUCTION}

Learning based on the use of technology becomes something urgent to do. The use of technology has to be accommodated in learning English because it could optimize an effective learning for the sake of catching the objectives of learning. It will be better and fun when teacher combinesthe teaching with the use of technology. Associated with learning
English, the government has implemented a policy to make English as a subject from junior high school to high school. This policy is expected to continue intensively and comprehensively related to what has been achieved by students in elementary school, especially in relation to English. English is given from grade IV, V, and VI and has become a local content of the curriculum. 
However, the condition in the real classroomwas different from what was expected. In fact, the government policy has not had an effect that is in line with what is expected regarding on the achievement of English competence and competence in the appropriate use of technology. Then, the process of learning English seemed to be implemented conventionally (less creative and interactive). Another point was the teaching was focused more on the use of student's worksheet (LKS) without looking at aspects of its usefulness to everyday life activities.

There are three factors that the researchers say are not achieving this: first, the curriculum developed at this time has not been maximally accommodated by teachers; secondly, the absence of an English textbook that incorporates elements of maximizing the use of technology in the learning process; third, teacher pedagogic competencies that still need to be improved in contextualizing the use of technology in the learning process of English (there is a tendency LKSoriented).

This study produces the output of English-language interactive video lessons of junior high school students aimed at improving students' English skills through a more enjoyable and contextual learning. The content of the interactive video is related to the competencies that should be owned by junior high school students. With the use of interactive video media, his hope can make English learning more meaningful and entertaining so that the end of the process is improving students' English proficiency.

The results of observations and interviews conducted by researchers as an English teacher in class VII C SMP N 2
Penebel indicated that students have difficulty in developing speaking competence. Presentation of material lessons have been focused on theory and grammar. As a result, many students are good at understanding the theory so as to get good grades in written evaluations but they seemed to be lack of speaking skills.

In learning English, students still look less active and responsive, interaction among students is also lacking. It also appears that students are closed and embarrassed to ask the teacher about the subject matter that has not been understood. It caused the students to find difficulties in understanding the material presented by the teacher. Difficulty in understanding the material causes the low competence of speaking students.

In addition, learning is still dominated by teachers so that less good student activity. Most students experience boredom in learning English largely due to teacher centered factors. With the lack of understanding and learning activities of these students have an impact on learning achievement that is generally less satisfactory.

From the discussion with the English teacher, it is stated that it is necessary to select the learning model that can improve the students' speaking competence. The model to be applied is learning using interactive video media. As cited in Sajidan (2010), this method is in harmony with the situation in the modern era where ICT-based learning (information communication and technology) is developed. Based on the above description, then conducted research related to the making of interactive video learning media.

\section{Research Problems}


With reference to the background that focuses on the importance of creativity in the use of technology, the problems in this study can be formulated as follows:

1. How to generate interactive videobased English teaching materials for junior high school students?

2. Is interactive video effectively used as a medium of learning in the learning process of English (which leads to increased student learning motivation)?

\section{Research Objectives}

By considering the formulation of the problem, the purposes of this study are as follows:

1. To produce English-language interactive video-based teaching materials for junior high school students.

2. To find out if interactive video is effectively used as a medium of learning in English learning process.

\section{LITERATURE REVIEW}

\section{Overview}

Allwright (1990) says that text books are generally too rigid to serve as a single source of learning. In other words learning is not directed to the real atmosphere where language should be used in different contexts and situations. Paul (200) mentions that the strategy of learning a second language or foreign to beginner learners should be directed to the achievement of competence and confidence (confidence).

The target of language learning is acquisition, not merely language learning. Krashen (1990) defines acquisition as the acquisition of language by self-effort. In other words, the learners (especially the beginner level) get a pleasant impression in learning the language so as to cultivate the desire to learn continuously. In other words, learning given at school should be able to give encouragement to students to be able to continue and develop their learning process outside the classroom by using the English they learn in real life.

\section{Core Competence and Basic Competence of Grade VII English SMP / MTs}

There are four core competencies

in learning English, such as:

1. KI-1 (Religious Attitudes)

2. KI-2 (Social Attitude)

3. KI-3 (Knowledge)

4. KI-4 (Skill)

\section{Learning Process}

The learning process in the 2013 curriculum uses a scientific approach: activity sequences through the process of observing. In this process, students read / watch / listen to examples of texts being studied from various sources, directly and / or recorded with respect to social functions, text structures, language elements, and format of delivery / writing.Then, the process of questioning. With guiding questions from teachers, learners' question are varied according to the topic / learning materials, such as social functions, phrases and text structure etc. After having those things, the next is the process of exploring / experimenting with reading / listening / watching other examples of the text he or she studies. The next process is to associate / analyze. Conducted in guided group work to be able to mention the social functions, expressions and structure of the text, linguistic elements and formatting of the type of text that is being studied. Input from teacher and friend from every result of group work were delivered. The last process is communicating. 


\section{Assessment Process}

Assessment in the 2013 curriculum uses authentic assessment. Authentic assessment is a significant measurement of the learning outcomes of learners for the areas of attitude, skills and knowledge. Types of assessment that are used are as follows:
a. Performance assessment
b. Project appraisal
c. Portfolio assessment
d. Written assessment

\section{Video as Media of Learning}

Media in the learning process tends to be interpreted as graphic, photographic, or electronic tools to capture, process, and rearrange visual or verbal information. Regarding on this case, educational media is used in the context of communication and interaction of teachers and students in the learning process. Learning media can clarify the presentation of messages and information so as to facilitate and improve the process and learning outcomes.

Video as the media of learning can be classified into Audio Aids Media (AVA) or media that can be seen or heard. In this case Interactive Learning Video (ILV) is a media tool that can be used in the classroom as a means of delivering educational materials through visual presentation (pictures) and audio (voice). ILV combines the power of video as a learning tool and interactivity between the audience and the content of the material. Video is an effective learning tool because it allows teachers and students to watch and learn from other teachers' learning practices.

However, the video itself is a passive medium that is typically watched by viewers without interaction with video content. Interactive learning videos encourage viewers to interact with video content to some degree - through questions, pauses for discussion, integration of learning documents (such as Word files), and multimedia techniques such as audio and text narration - thereby increasing the learning potential of videos.

The combination of video and interactivity makes ILV a very effective tool that can be used to deliver educational materials and promote active classroom discussions and learning and professional development environments.Benefits of ILV media usage are (1) can stimulate the active participation of students; (2) presenting messages and information simultaneously for all students; (3)generating motivation to learn; and (4) overcoming the limitations of space and time.

\section{RESEARCH METHODS \\ Research Design}

The design and steps in this study used the action research design (Action Research). This design is appropriate for creating interactive video-based English teaching materials to solve existing problems. The action research design was used to evaluate whether interactive video is effectively used as a medium of learning in the process of learning English to improve student learning motivation. This is in line with the quotation below.

"Goal of action research is to solve problems of local concern." (Fraenkel, Wallen and Hyun, 2012, pg.596) "Use action research when you want to
evaluate whether what you are doing is
influencing your own or other people's
learning, or whether you need to do something 
different to ensure that it is." (McNiff and Whitehead, 2006, pg.1)

\section{Location and Subject Research}

This research was conducted on English subject of grade VII C SMP students in Penebel Subdistrict, Tabanan District, Bali Province. There were 22 male and 19 female students. This class was chosen because of the problems related to the ability to speak in the process of learning English. With the lack of accommodating the use of technology.

\section{Data Analysis}

The data of the study were collected using document studies, observation and interviews. Data were analyzed quantitatively and qualitatively. This research also involves the role of classroom teachers and students who are later called collaborators.

Stages of Making Interactive Learning Video

The interactive video making includes three stages: pre production, production and post production.

a. Pre-Production Stage

Activities in the pre-production stage included determining the identification of the program used and the preparation of English learning content.

b. Production Stage

At the stage of production done the preparation of content, image and sound and data storage using PC hardware.

c. Post-Production Stage

After the production has been completed, the next stage is post production which is the final stage of making video media, in this case, editing, feasibility test, and covering (packaging cover) which then continued to production.

\section{RESULTS AND DISCUSSION Results}

The students of grade VII C class come from different backgrounds of elementary school (SD) so that they have different English language skills. But there are similarities among them: the ability to speak is still low. For that, researcher conducted a research with two cycles and divided each cycle into four stages: planning, action, observation, reflection.

Cycle I

Planning

The researcher develops a lesson plan for the speaking aspect that includes standardcompetency, indicators, learning steps and rubrics for assessment. The standard of competence is understanding the meaning in transactions and interpersonal conversations is very simple to interact with the immediate environment. Basic competence interacts with the immediate environment which involves greeting, introducing themselves / others, asking for something.

The next stage is the implementation of a simulation dialogue by 1) showing an interactive video that contains a dialogue about greeting unknown people, 2) repeating the video and providing examples of dialogue and students mimicking,) guiding students to imitate related phrases, 4) facilitating students to answer interactive questions from the characters in the video, 5) facilitating students to practice in pairs.

Action

At this stage, students practiced to conduct a dialogue on related topics together with his partner. Students are given an existing transcript of the dialogue and putting it in front of the class. At the next meeting, still in the stage of the action, the students put in a dialogue 
without bringing the transcript. With the same theme of conversation, students are more enjoying their conversations because they have been practicing and have been sampled from interactive video shows. The end of cycle 1 is posttest.

\section{Observation}

Activity in cycle 1 goes well and it is known that students are more enthusiastic in following learning. When the interactive video media is displayed the students seem very interested in imitating and following the conversations in the video well. They also asked each other and answered alternately with the narrator in the video. At the end of the show they are more excited when they have to fill the conversation in their own voice. Students look engrossed in learning with their partners and when they find it difficult to ask questions with their teachers.

Reflection

One thing to note in this reflection is the high spirit of students in following the lesson. This is because an interactive video show is able to make students more interested because of the conversation model in the show. Weaknesses that may need to be fixed are topics that are still monotonous so students can not fully improvise. As a precaution it is necessary to allow the students to decide on their own topic of conversation.

Cycle II

Planning

From the reflection of cycle 1 related to the advantages, shortcomings and suggestions that exist then the researchers decided to provide flexibility to students in determining the topic of conversation in accordance with their choice of each.

Action
In this second stage the students practice to conduct a dialogue on the topic of their choice and together with their partner. Students create and develop their own transcript of dialogue and put it into practice in front of the class. At the next meeting, still in action stage, students practice dialogue without carrying transcripts. Students are also allowed to improvise the conversations they have made outside the transcripts they have made. The end of cycle 2 is posttest implementation. Same with previous cycles of students in pairs of conversational practices with their spouses in front of the class.

Observation

Activities in cycle 2 seem more natural than cycle 1 . Teachers also show some other examples of interactive videos that help students in compiling transcripts, practicing in pairs and displaying it in front of the class. In this phase, more interaction between students and teachers, whether in the form of asking or asking directions related to the conversation being exhibited. Students are more engrossed in learning with their spouses and when they have difficulty asking questions with their teachers. The ability of each student in a paired conversation is also more increased compared with cycle 1 .

Reflection

One of the highlights of this cycle 2 action is the increased ability of students to pour their ideas into transcripts and express them in conversation. In the reflection sheet they also feel more comfortable doing a conversation that was preceded by an interactive video view as a model. As an input to the next research is the development of interactive video media as a means of learning for other abilities, with a more diverse theme. 


\section{Discussion}

In the early cycle, the value is 2.70 which is still far from the minimum passing grade of 3.00. It shows that, there are things that need to be improved in the learning process. Then, in cycle 1 , the learning process is done by using video, as part of the result of reflection on the early cycle. Changes seen in enthusiastic students in following the learning process. This has an impact on the increase in student grades from 2.70 to 2.96 . However, the value does not meet the minimum passing grade.

To accommodate that notion, researcher did reflections related to the utilization of the video. In the learning process, conventional techniques are no longer used to run the teaching process. Video was provided for students was accommodated by the application of watch-Think-Pair-Share techniques. Students were asked to watch a video, then they were asked to think about related issues that might be discussed with reference to that topic taught. After thinking about the idea, they were asked to discuss with their seatmates then proceeded to divide to all friends in the class.

Accommodating learning videos with proper application of techniques, in this case watch-Think-Pair-Share, provided a good result. The value of students who in cycle 1 was 2.96 increased to 3.31. This indicates that the use of English-language video by accommodating the application of watchThink-Pair-Share technique indicated that the learning media without being accommodated with appropriate techniques has the potential to improve the effectiveness of the learning media, either in the improvement of speech or mastery of the material.

\section{Students' Motivation}

The results of this study also showed that the use of interactive learning video could increase students' motivation in following the lesson. English lesson became less boring because they are not only classical and teacher-centered, but it could make them involved in teaching and learning process so that they got active to speak. One of the methods is the use of interactive video media in English learning that is accommodated by the application of watch-Think-Pair-Share techniques. The results of the questionnaire showed that the comparison was related to the preferred responses A (Strongly Agree), B (Agree), $\mathrm{C}$ (Disagree), and D (Strongly Disagree), i.e. $63.63 \%, 29.15 \%, 7.22 \%$ and $0 \%$.

\section{CONCLUSIONS AND SUGGESTIONS Conclusions}

The results of the analysis and discussion concluded that the use of interactive learning video is successful in 2 aspects i.e. 1) with the application of watch-Think-Pair-Share technique on the use of interactive learning video managed to improve students' speaking ability. 2) it also improves students' motivation in learning.

\section{Suggestions}

In connection with the research described above, suggestions may be made as follows:

1. For other English teachers the use of interactive video media can be used to improve speech and motivation students in following learning.

2. Learning by this method should be fully prepared as well as possible, 
because the success of learning is determined by the preparation.

\section{REFERENCES}

Arikunto, S. (2006). Penelitian Tindakan Kelas. Jakarta: Bumi Aksara.

Brown, H. D. (2001). Teaching by Principles: An Interactive Approach to Language pedagogy. N.Y: Longman.

Dantes, N. (2012). Metode Penelitian. Yogyakarta: Andi Yogyakarta.

Dick, W. and Carey, L. (1990). The Systematic Design of Instruction. Second Edition. Illinois: Scott, Foresman and Company.

Ginarto. (2014). "Pembelajaran Bahasa Inggris SMP berdasarkan Kurikulum 2013".

Downloaded fromhttp://ginarto.guruindonesia.net/artikel_detail49704.html, on $25^{\text {th }}$ June 2015.

Krashen, S. (1981). Second Language Acquisition and second language learning. Oxford: Pergamon.

Krashen, S. (1982). Principles and practices in second language acquisition. London: Pergamon.

Nurkamto, J. (2008). Metode Pengajaran Bahasa Inggris.

Moleong, L. J. (2005). Metodologi Penelitian Kualitatif. Bandung: PT. Remaja Rosdakarya

Mustaji. (2012). Desain Pembelajaran dengan Menggunakan Model
Pembelajaran Kolaborasi untuk Meningkatkan Kemampuan Berkolaborasi. Downloaded fromhttp://pasca.tp.ac.id/site/desainpembelajaran-dengan-menggunakanmodel-pembelajaran-kolaborasiuntuk-meningkatkan-kemampuanberkolaborasi, on $25^{\text {th }}$ June 2015.

O’Malley, J. M. dan Pierce, L. V. (1996). Authentic Assessment for English Language Learners. Practical Approach for Teachers. Ontario: Addison: Wesley Publishing Company.

Rahman, A. (2008). Teaching English to Children.

Sajidan. (2010). ICT based learning.

Sardiman. (2001). Interaksi dan Motivasi Belajar Mengajar. Jakarta: Raja Grafindo Persada.

Sugiyono. (2010). Metode Penelitian Kuantitatif, Kualitatif, dan $R \& D$. Bandung: Alfabeta.

http://wapikweb.orgaccessed onThursday, $25^{\text {th }}$ June 2015 at. $17.40 \mathrm{pm}$.

http://jurnal-online.um.ac.idaccessed onThursday, $25^{\text {th }}$ June 2015 at. $17.40 \mathrm{pm}$.

http://eprints.uny.ac.idaccessed onThursday, $25^{\text {th }}$ June 2015 at 17.52 pm.

http://digilib.uinsby.ac.idaccessed onThursday, $25^{\text {th }}$ June 2015 at 18.07 pm. 